\title{
ANALISIS KINERJA DALAM MENDETEKSI STUDENT LOSES BERDASARKAN NILAI GAIN DENGAN SPLITE FEATURE REDUCTION MODEL PADA ALGORITMA C4,5
}

\author{
STMIK Mikroskil \\ Medan, Indonesia, 20212 \\ ${ }^{1}$ luckyman513@gmail.com, 2erwin@mikroskil.ac.id, ${ }^{3}$ roni@mikroskil.ac.id
}

\begin{abstract}
Abstrak- Perguruan tinggi diharapkan mampu menghasilkan sumber daya manusia yang berpengetahuan juga kreatif. faktor penilaian perguruan tinggi adalah persentase kemampuan mahasiswa dalam menyelesaikan studi. Saat ini, masalah student loses dan faktor-faktor yang mempengaruhinya telah menjadi topik yang menarik untuk diteliti. Institusi perlu mendeteksi kinerja mahasiswa yang berstatus "student loses" sehingga dapat diidentifikasi. Dengan metode klasifikasi algoritma C4.5 dalam mengambil keputusan yang dianggap memiliki kinerja yang baik, tetapi algoritma C4.5 memiliki beberapa kelemahan terhadap data yang tidak seimbang, yaitu dataset yang berbeda dua kelas yang berbeda antara kelas mayoritas dan kelas minoritas, berpengaruh pada algoritma $\mathrm{C4.5}$, yang menghasilkan nilai hasil akurasi kurang optimal pada algoritma C4,5 untuk mengurangi pengaruh ketidakseimbangan kelas pada klasifikasi C4.5, maka perlu dilakukan pendekatan metode Split Feature Reduction Model hal ini dilakukan untuk memberi bobot pada setiap fitur yang direkomendasikan, sehingga ditemukan fitur yang merupakan klasifikasi yang kuat, berdasarkan perangkingan pada setiap fitur agar dapat direkomendasikan pada klasifikasi C4.5 dalam proses klasifikasi Hasil menunjukkan bahwa, kinerja akurasi klasifikasi C4.5 pada dataset mahasiswa dengan pendekatan SFRM sebelum proses Pengujian, 10 fold cross-validation, menunjukkan tingkat akurasi klasifikasi yang lebih baik yaitu akurasi $98 \%$ dalam penanganan ketidakseimbangan kelas.
\end{abstract}

Kata Kunci-Student loses klasifikasi C4.5, Split Feature Reduction Model, Fold Cross-Validation.

Abstract-College is expected to produce knowledgeable and creative human resources. Factors for college grades are students' ability to complete their studies. At present, students who have problems losing and the factors that influence it have become interesting topics to be fixed. Students with the status of "students loses" in order to support. With the classification method C4.5 algorithm in making decisions that are considered to have a good rating, but $\mathrm{C} 4.5$ algorithm analysis has a level of weakness against unbalanced data, namely different datasets two different classes between the corresponding class and a larger class, which examined in C4.5 algorithm, which results in less optimal test results on the $\mathrm{C} 4.5$ algorithm to reduce class imbalance in the C4.5 classification, it is necessary to use the Split Feature Reduction Model method this is done to give weight to each feature sought, can be found a feature which is a strong classification, based on ranking of each feature so that it can be recommended in the $\mathbf{C 4 . 5}$ classification in the classification process. shows better classification accuracy completed $98 \%$ in handling class imbalances.

Keywords-Student loses classification C4.5, Split Feature Reduction Model, Fold Cross-Validation.

\section{PENDAHULUAN}

Perguruan tinggi merupakan suatu instansi pengelola pendidikan akademik tingkat lanjut bagi mahasiswa. Lima lembaga perguruan tinggi diantaranya adalah universitas, institut, sekolah tinggi, akademi dan politeknik. Pusat Statistik Pendidikan Badan Penelitian dan Pengembangan Departemen Pendidikan Nasional Republik Indonesia memiliki data yang menyebutkan bahwa jumlah lembaga penyelenggara perguruan tinggi mengalami peningkatan setiap tahunnya. Pada tahun 2018 tercatat 3171 perguruan tinggi diselenggarakan di Indonesia.
Perguruan tinggi diharapkan mampu menghasilkan intelektual muda yang berkualitas dan menghasilkan sumber daya manusia yang berpengetahuan juga kreatif, semakin meningkat jumlah sumber daya manusia yang berkualitas yang menjadi outcome bagi Institusi perguruan tinggi. Salah satu faktor penentu penilaian kualitas perguruan tinggi adalah persentase kemampuan mahasiswa untuk menyelesaikan studi tepat waktu. Berdasarkan matriks penilaian instrument akreditasi program studi (BAN-PT) [1]. bahwa unsur penilaian akreditasi Perguruan Tinggi, data yang didapat dari Pusat Statistik Pendidikan Badan Penelitian dan Pengembangan Departemen Pendidikan 
Nasional Republik Indonesia [2] pada tahun akademik 2014/2015 sampai dengan 2017/2018 menunjukkan bahwa perguruan tinggi swasta di Indonesia menerima rata-rata sebanyak 966.587 mahasiswa baru dan meluluskan rata-rata 691.124 mahasiswa setiap tahunnya atau hanya mencapai $72 \%$ saja dari data tersebut diketahui bahwa $28 \%$ mahasiswa tidak diketahui keberadaanya. status tersebut bisa jadi karena mahasiswa menempuh studi tidak tepat waktu, memiliki status tidak aktif, atau bahkan student loses. Universitas Pembangunan Pancabudi merupakan salah satu perguruan tinggi swasta di Sumatera Utara yang memiliki 19.881 mahasiswa. Pada tahun ajaran 2014/2015 sampai dengan data 2018/2019 meluluskan $17 \%$, terdapat $21 \%$ dengan status tidak aktif. Tingginya persentase mahasiswa yang memiliki status tersebut menyebabkan tingginya persentase mahasiswa lulus tidak tepat waktu. Hal ini menjadi sangat penting bagi Institusi mengingat persentase mahasiswa lulus tepat waktu adalah merupakan unsur penting penilaian akreditasi yang ditetapkan oleh Badan Akreditasi Nasional. Dan Institusi perlu melakukan tindakan untuk mengetahui faktor-faktor penyebab mahasiswa memiliki status student loses. Institusi perlu melakukan prediksi prilaku terhadap mahasiswa dalam mencegah kegagalan akademik secara dini untuk mencegah student loses. Database institusi perguruan tinggi menyimpan data akademik, administrasi biodata yang terkait dengan mahasiswa dan Data tersebut apabila digali dengan tepat maka dapat diketahui pola atau knowledge untuk mengambil keputusan [3]. Serangkaian proses mendapatkan knowledge atau pola dari data base disebut dengan data mining (Witten, Ian 2016). Data mining dapat membantu mengatasi masalah dengan menganalisis data yang telah ada dalam database. Diantaranya, Penelitian yang dilakukan oleh Nagy, Marcell [4] , melakukan perbandingan untuk memprediksi mahasiswa student losses dengan jumlah 15.825 data akademik mahasiswa dari Universitas Teknologi dan Ekonomi Budapest terdaftar antara 2010 sampai dengan 2017 dengan beberapa algoritma diuji dengan 10-fold crossvalidation dan penelitian Kelly J. de O. Santos [5] di Federal University of Sergipe (UFS) Brazil. Mahasiswa gagal pada semester 4. Prodi System Iinformation dan Computer Science dengan menggunakan 23,690 data set mahasiswa.

\section{LITERATURE REVIEW}

\section{DATA MINING}

Penambangan data menghasilkan pola yang dapat ditranformasi dalam bentuk atau format matematika. Meskipun dimungkinkan untuk mengartikan makna dari permukaan ruang vektor, pola yang diperoleh dari objek yang lebih kompleks mungkin tidak mudah ditafsirkan bahkan para ahli itu sendiri. Penambangan, data semakin rumit, dan juga pola yang diperoleh jauh lebih kompleks [6] Penambangan Data diartikan sebagai proses untuk menemukan hubungan, pola, dan tren baru dengan menyaring sejumlah data, disimpan dalam penyimpanan, menggunakan teknik pengenalan model seperti teknik Matematika dan Statistik. [7] Penambangan data adalah proses kunci ketika suatu metode diterapkan untuk menemukan (knowledge) pengetahuan yang berharga dan tersembunyi dari database.

\section{Algoritma $C 4,5$}

Algoritma C4.5 adalah salah satu algoritma klasifikasi yang berfungsi untuk membuat pohon keputusan. [8]. Algoritma C4.5 merupakan algoritma klasifikasi desicion tree termasuk paling banyak digunakan karena memiliki keunggulan dibandingkan algoritma lainnya, Kelebihan algoritma C4.5 mudah diimplementasikan, dengan akurasi yang dapat diterima, dan efisien dalam penanganan atribut tipe diskrit serta dapat menangani atribut tipe numerik [9].

\section{Splite Feature Reduction Model}

Teknik reduksi data yaitu memperoleh data volume kecil dari volume besar tetapi masih mempertahankan integritas data asli, Tujuan pengurangan fitur adalah untuk menghilangkan fitur yang tidak relevan [10]. Pemilihan fitur berdasarkan Gain Ratio menggunakan metode ranker. Ranker bekerja dengan menyortir fitur dari nilai gain tertinggi ke nilai gain terendah.

\section{Cross Validation}

Validasi silang adalah metode statistik yang dapat digunakan untuk mengevaluasi kinerja suatu model atau algoritma di mana data dipecah menjadi dua himpunan bagian yaitu data proses pembelajaran dan data validasi / evaluasI

\section{Confusion Matrix}

Evaluasi terhadap pengukuran kinerja model menggunakan confusion matriks, metode ini adalah alat yang berguna untuk menganalisis seberapa baik pengklasifikasian dapat mengidentifikasi fitur dari kelas yang berbeda [11]. Confusion Matrix dapat membantu menunjukkan detail kinerja klasifikasi dengan menyediakan sejumlah fitur kelas yang akurat dan tidak akurat. [12].

$$
\begin{aligned}
& \text { Accuracy }=\frac{T P+T N}{(T P+F N)+(F P+T N)} \ldots \ldots \ldots \ldots \ldots \ldots \ldots[2.1]
\end{aligned}
$$

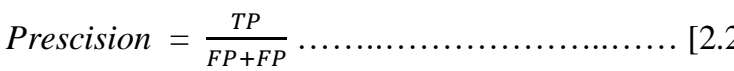

$$
\begin{aligned}
& \text { Recall }=\frac{T P}{T P+F N}
\end{aligned}
$$




\section{METODOLOGI}

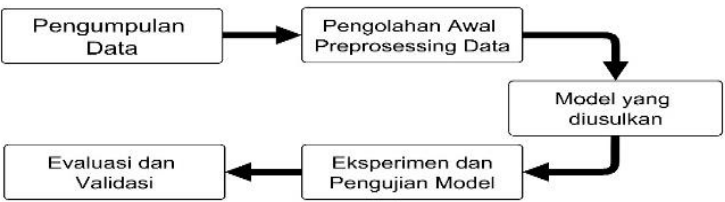

Gbr 1. Model Tahapan Penelitian

Langkah-langkah pemrosesan adalah sebagai berikut untuk mendapatkan hasil:

1. Pengumpulan data

2. Preprosesing data.

3. Penentuan model yaitu Splite feature reduction model dengan metode penentuan rangker berdasarkan nilai gain tertinggi.

4. Penerapan klasifikasi algoritma $\mathrm{C} 4,5$.

5. Analisis hasil dan evaluasi. pada

Pada proses akuisisi pengumpulan data mahasiswa database SIPT Universitas Pembangunan Pancabudi Dengan jumlah 3900 record, tahun ajaran 2017/2018, program studi manajemen dan ilmu komputer berupa data akademik dan data non- akademik. dan penelitian ini memiliki struktur kurikulum yang sama. dataset diperoleh dengan melakukan quenbvbry data pada langkah preprosesing data, pertama-tama peneliti memeriksa elemen yang hilang, menerapkan analisis semantik, dan kemudian normalisasi. Untuk langkah klasifikasi,

\section{ANALISIS DAN HASIL}

Dari proses perhitungan untuk mencari nilai gain rasio menghasilkan beberapa atribut untuk diurutkan berdasarkan nilai gain dan Pemilihan fitur menggunakan metode peringkat, pemilihan fitur dari nilai gain tertinggi ke nilai gain terendah, Setelah menerapkan Gain Ratio, penulis mendapatkan 20 fitur secara rangker. Pembagian fitur mengklasifikasikan 4 tingkat kelompok. split. Split 1 terdiri dari 8 fitur, Split 2 terdiri dari 12 fitur, Split 3 terdiri dari 16 fitur, dan Split 4 terdiri dari 20 fitur. Pada tahap prepocessing, fitur yang dipilih adalah fitur yang memiliki nilai gain di atas 0,01 Rasio perolehan adalah modifikasi dari perolehan informasi untuk mengurangi bias fitur yang memiliki banyak cabang. Berikut tabel pembagian fitur berdasarkan nilai gain.
TABEL I

PENENTUAN PERINGKAT BERDASARKAN NILAI GAIN RASIO TERTINGGI

\begin{tabular}{|c|c|c|c|c|c|c|}
\hline NO & ATRIBUT & RANG KER & $\begin{array}{c}\text { SPLI } \\
\text { T } 4\end{array}$ & $\begin{array}{c}\text { SPLI } \\
\text { T } 3\end{array}$ & $\begin{array}{c}\text { SPLI } \\
\text { T } 2\end{array}$ & $\begin{array}{c}\text { SPLI } \\
\text { T } 1\end{array}$ \\
\hline 1 & SKS 20182 & 0.6034823 & & & & \\
\hline 2 & STATUS AKADEMIK & 0.4938867 & & & & \\
\hline 3 & IPS 20181 & 0.4316499 & & & & \\
\hline 4 & SKS 20172 & 0.4214887 & & & & \\
\hline 5 & SKS 20181 & 0.3886703 & & & & \\
\hline 6 & IPK & 0.269066 & & & & \\
\hline 7 & IPS 20172 & 0.2251757 & & & & \\
\hline 8 & IPS 20171 & 0.1756792 & & & & \\
\hline 9 & STATUS PERKAWINAN & 0.0347005 & & & & \\
\hline 10 & UMUR & 0.026295 & & & & \\
\hline 11 & JENISKELAMIN & 0.0186973 & & & & \\
\hline 12 & ASAL SEKOLAH & 0.0088473 & & & & \\
\hline 13 & SUMBER BIAYA & 0.008818 & & & & \\
\hline 14 & STATUS BEKERJA & 0.0074187 & & & & \\
\hline 15 & KOTA DOMISILI & 0.0057709 & & & & \\
\hline 16 & PRODI & 0.0050674 & & & & \\
\hline 17 & AGAMA & 0.0038026 & & & & \\
\hline 18 & JENIS PEKERJAAN ORTU & 0.0028058 & & & & \\
\hline 19 & GAII ORTU & 0.0024066 & & & & \\
\hline 20 & STATUS DOMISILI & 0.0019868 & & & & \\
\hline
\end{tabular}

TABEL II

HASIL KINERJA DENGAN PROSES SFRM DENGAN

\begin{tabular}{|c|c|c|c|c|c|c|c|c|c|c|}
\hline $\begin{array}{c}\text { Validasi } \\
\text { / } \\
\begin{array}{c}\text { Confide } \\
\text { nce }\end{array}\end{array}$ & TP & FP & TN & FN & Akurasi & Presisi & Recall & $\begin{array}{c}\text { AUC } \\
\text { (optimis } \\
\text { tic) }\end{array}$ & AUC & $\begin{array}{c}\text { AUC } \\
\text { (pessim } \\
\text { istic) }\end{array}$ \\
\hline Split 1 & 2406 & 84 & 1269 & 141 & $94.23 \%$ & $96.77 \%$ & $94.46 \%$ & 0.986 & 0.981 & 0.976 \\
\hline Split 2 & 2452 & 77 & 1276 & 95 & $95.59 \%$ & $96.96 \%$ & $96.27 \%$ & 0.989 & 0.985 & 0.98 \\
\hline Split 3 & 2506 & 20 & 1333 & 41 & $98.44 \%$ & $99.21 \%$ & $98.39 \%$ & 0.999 & 0.999 & 0.999 \\
\hline Split 4 & 2486 & 25 & 1327 & 62 & $97.77 \%$ & $99.00 \%$ & $97.57 \%$ & 0.997 & 0.995 & 0.991 \\
\hline
\end{tabular}

Pada split 3 proses pengukuran SFRM terdapat 3900 jumlah data pengukuran pada kelas tepat waktu (Yes) 2506 data yang diprediksi benar (TP) dan 20 data prediksi salah (FP). Kelas cenderung student loses (No). Diperoleh 1333 data diprediksi benar (TN). serta 41 data diprediksi tidak sesuai (FN) pada kelas student loses pada Split 3. Dengan nilai AUC 0,999.

\section{Hasil Analisis Kinerja Klasifikasi C4.5 Dengan Confusion Matrix}

Pada Tabel 2. diperoleh akurasi tertinggi pada Split 3 dengan 98,44\%. Jadi, Split 3 dengan 18 fitur pilihan yaitu fitur yang paling berpengaruh terhadap klasifikasi untuk meningkatkan akurasi algoritma C4.5 dengan menerapkan model pengurangan fitur split. Berikut grafik peningkatan akurasi di setiap pemisahan pada masing-masing split, 


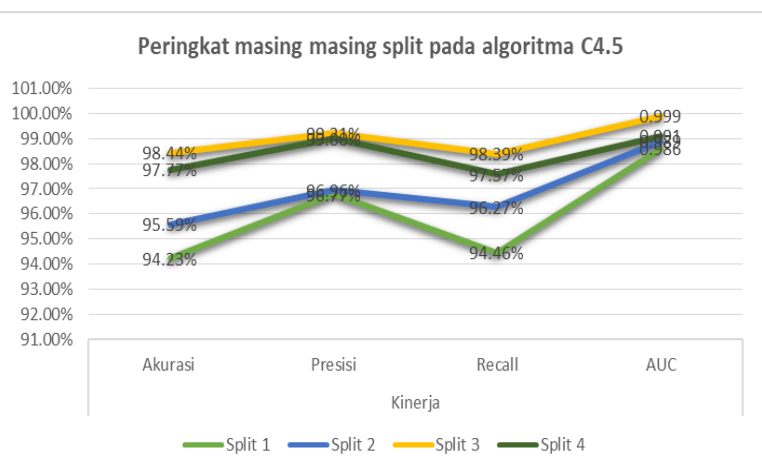

Gbr 2. hasil akurasi dan peringkat masing masing split dengan algoritma $\mathrm{C} 4.5$

Dari gambar 2 menunjukan model algoritma C.45 dengan penanganan (SFRM) lebih baik dalam penanganan ketidakseimbangan kelas pada dataset mahasiswa dengan tingkat diagnosa Nilai AUC adalah klasifikasi (Excellent Classification). Hal ini menunjukkan bahwa dengan menerapkan SFRM pada pengklasifikasi C4.5 dapat menangani permasalahan ketidakseimbangan kelas yang menjadi kelemahan pada algoritma $\mathrm{C} 4,5$ pada dataset mahasiswa, dan dari hasil pengukuran tersebut menunjukan split 3 adalah klasifikasi nilai tertinggi dari split yang lainnya, hasil akurasi telah meningkat dibandingkan dengan split lainya keakuratan Dataset mahasiswa dengan menggunakan algoritma C4.5 Hasil lebih baik pada Split 3 dengan 98,44\%. Kemudian, peningkatan akurasi dengan menerapkan SFRM Hasil akurasi setiap pemisahan setelah diterapkan Algoritma C4.5.

Hasil Kinerja Proses Pengujian Dengan Cross Validation

TABEL III

HASIL KINERJA PROSES PENGUJIAN DENGAN CROSS VALIDATION

\begin{tabular}{|l|l|l|l|l|l|l|l|l|l|l|}
\hline $\begin{array}{l}\text { Cros } \\
\text { validati } \\
\text { on dan } \\
\text { C4,5 }\end{array}$ & TP & FP & TN & FN & $\begin{array}{l}\text { Akurasi / } \\
\text { micro } \\
\text { average }\end{array}$ & $\begin{array}{l}\text { Presisi / } \\
\text { micro } \\
\text { average }\end{array}$ & $\begin{array}{l}\text { Recall / } \\
\text { micro } \\
\text { average }\end{array}$ & $\begin{array}{l}\text { AUC } \\
\text { (optimisti } \\
\text { c) / micro } \\
\text { average }\end{array}$ & $\begin{array}{l}\text { AUC / } \\
\text { micro } \\
\text { average }\end{array}$ & $\begin{array}{l}\text { AUC } \\
\text { (pessimist } \\
\text { ic) / } \\
\text { micro } \\
\text { average }\end{array}$ \\
\hline split 1 & 2378 & 99 & 1254 & 169 & $\begin{array}{c}92.95 \% \\
+/-1.08 \%\end{array}$ & $\begin{array}{c}95.47 \% \\
+/-1.42 \%\end{array}$ & $\begin{array}{c}93.68 \% \\
+/-1.52 \%\end{array}$ & $\begin{array}{c}0.974+/- \\
0.012\end{array}$ & $\begin{array}{c}0.966+/- \\
0.014\end{array}$ & $\begin{array}{l}0.959+/- \\
0.016\end{array}$ \\
\hline split 2 & 2385 & 123 & 1230 & 162 & $\begin{array}{c}92.69 \% \\
+/-1.19 \%\end{array}$ & $\begin{array}{c}95.11 \% \\
+/-1.29 \%\end{array}$ & $\begin{array}{c}93.64 \% \\
+/-1.44 \%\end{array}$ & $\begin{array}{c}0.969+/- \\
0.010\end{array}$ & $\begin{array}{c}0.957+/- \\
0.012\end{array}$ & $\begin{array}{c}0.949+/- \\
0.014\end{array}$ \\
\hline split 3 & 2466 & 55 & 1298 & 81 & $\begin{array}{c}96.51 \% \\
+/-1.04 \%\end{array}$ & $\begin{array}{c}97.83 \% \\
+/-1.08 \%\end{array}$ & $\begin{array}{c}96.82 \% \\
+/-1.30 \%\end{array}$ & $\begin{array}{c}0.994+/- \\
0.003\end{array}$ & $\begin{array}{c}0.973+/- \\
0.011\end{array}$ & $\begin{array}{c}0.968+/- \\
0.013\end{array}$ \\
\hline split 4 & 2454 & 70 & 1282 & 94 & $\begin{array}{c}95.79 \% \\
+/-0.98 \%\end{array}$ & $\begin{array}{c}97.23 \% \\
+/-0.80 \%\end{array}$ & $\begin{array}{c}96.31 \% \\
+/-1.16 \%\end{array}$ & $\begin{array}{c}0.986+/- \\
0.008\end{array}$ & $\begin{array}{c}0.958+/- \\
0.019\end{array}$ & $\begin{array}{c}0.956+/- \\
0.019\end{array}$ \\
\hline
\end{tabular}

Pada split1 proses pengujian SFRM cross validation terdapat 3900 jumlah data, terdapat kelas tepat waktu (Yes) 2378 data yang diprediksi benar (TP) dan 99 data prediksi salah (FP). Kelas cenderung student loses (No). Diperoleh 1254 data diprediksi negatif (TN). serta 169 data diprediksi tidak sesuai (FN) pada kelas student loses. Dengan nilai AUC 0.974 +/- 0.012 micro average. Pada split2 proses pengujian SFRM cross validation terdapat 3900 jumlah data, terdapat kelas tepat waktu (Yes) 2385 data yang diprediksi benar (TP) dan 123 data prediksi salah (FP). Kelas cenderung student loses (No). Diperoleh 1230 data diprediksi negatif (TN). serta 162 data diprediksi tidak sesuai (FN) pada kelas student loses. Dengan nilai AUC 92.69\% +/- $1.19 \%$ micro average. Pada split 3 proses pengujian SFRM cross validation terdapat 3900 jumlah data, terdapat kelas tepat waktu (Yes) 2466 data yang diprediksi benar (TP) dan 55 data prediksi salah (FP). Kelas cenderung student loses (No). Diperoleh 1298 data diprediksi negatif (TN). serta 81 data diprediksi tidak sesuai (FN) pada kelas student loses. Dengan nilai AUC 0.994 +/0.003 micro average.

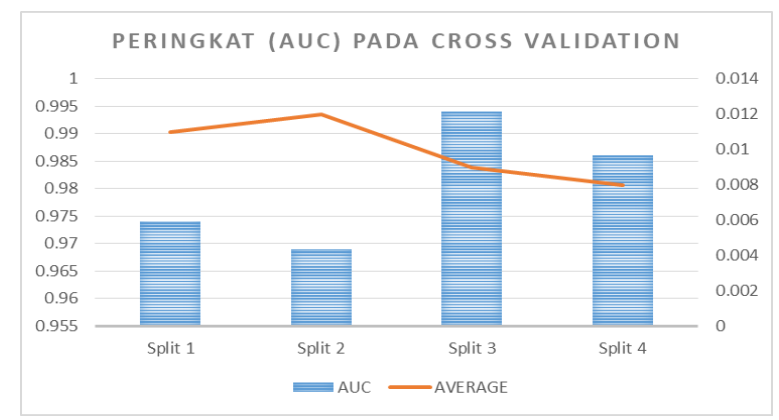

Gbr 3. Garafik peningkatan kinerja AUC pada pengujian cross validation menggunakan SFRM

Pada grafik diatas, AUC merupakan ukuran numerik untuk membedakan kinerja model dalam hasil pengukuran pada klasifikasi, nilai AUC yang tinggi menunjukkan kinerja yang lebih baik (Weiss, 2017). Dan seberapa sukses dalam memisahkan pengamatan positif dan negative (Branco, Paula, 2016) AUC menyediakan ukuran tunggal kinerja klassifikasi untuk mengevaluasi model mana yang lebih baik, pada gambar 3 dan dari hasil pengukuran tersebut menunjukan split 3 adalah klasifikasi nilai tertinggi dari split yang lainnya, hasil nilai AUC paling tinggi dibandingkan dengan Split lainya, dari pengujian cross validation model algoritma C4.5 dengan menerapkan seleksi fitur dengan SFRM pada Split 3 nilai AUC: 0.994 micro average 0.003 dengan Hasil terbaik diperoleh di Split 3 dengan 96,85\%. setelah dilakukan pengujian cross validation pada Algoritma C4.5, Akan tetapi pada pengujian ini terjadi penurunan akurasi di setiap split sebesar $1,5 \%$. 


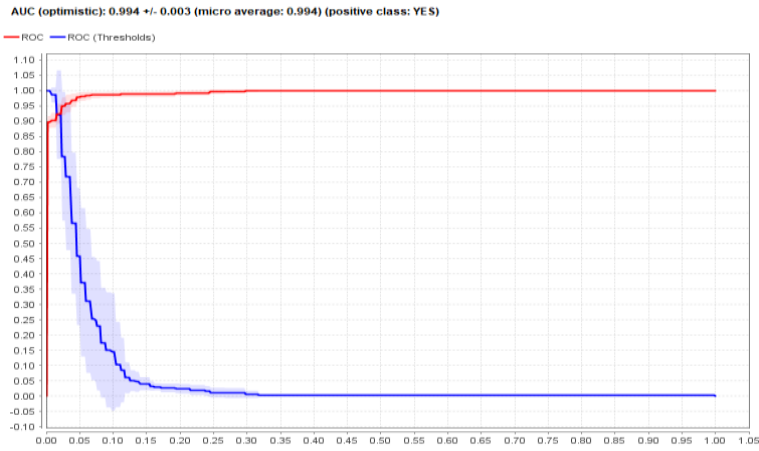

Gbr 4. ROC pada cross validation Split 3

Gambar 4. Menunjukkan kurva ROC kinerja model algoritma C4.5 dengan proses SRFM Split 3, pada pengujian 10-fold Cross validation maka nilai AUC (Area Under Curve) sebesar 0,994. Micro average 0.003 Maka tingkat akurasi didiagnosa sebagai klasifikasi sangat baik (Excelance classification). dan bias lebih mengecil ketika dengan proses SFRM dan Split 3 merupakan pengujian dengan nilai terbaik diantara split yang lainnya.

\section{PENUTUP}

Berdasarkan hasil penelitian yang dilakukan, dapat diambil kesimpulan sebagai berikut :

1. Penanganan terhadap Pengaruh ketidak seimbangan kelas Menggunakan Pendekatan SFRM dianggap mampu mengatasi permasalahan kelemahan klasifikasi algoritma C4,5. Untuk mengurangi pengaruh ketidakseimbangan kelas adalah Terdapat model prediksi Student loses yang memiliki kinerja lebih baik dari klasifikasi algoritma C4.5, sehingga kinerja klasifikasi algoritma $\mathrm{C} 4.5$ masih bisa ditingkatkan untuk memperbaiki model prediksi.

2. Menerapkan pendekatan Splite Feature Reduction Model dapat meningkatkan kinerja pengklasifikasi C4.5 dengan diagnosa klasifikasi sangat baik (Excellence Classification) dalam penanganan ketidakseimbangan kelas, selama proses validasi data training dan data testing dilakukan dengan metode 10-fold CrossValidation dan nilai AUC sangat baik (Excellence Classification) pada Split3, dan terjadi penurunan akurasi sebesar $1,5 \%$ pada setiap split pada saat dilakukan pengujian dengan metode 10-fold Cross Validation.

3. Perbandingan rating klasifikasi Split3 dengan klasifikasi menghasilkan akurasi tertinggi 98,44\% dan nilai AUC $0,994 \%$ merupakan nilai klasifikasi paling tinggi di antara split 1 , split 2 , split 4.

4. Faktor rendahnya kemampuan akademik, merupakan faktor paling berpengaruh dan diikuti faktor asal sekolah, domisili saat menempuh studi dan faktor pembiayaan adalah faktor yang mempengaruhi student loses

\section{REFERENS}

[1]. BAN-PT. (2015). Akreditasi Institusi Perguruan Tinggi. In Pedoman Penyusunan Borang. ban-pt.depdiknas.go.id

[2]. Dikti, P. D. dan I. I. (2017). statistik 2017. In Statistik Pendidikan Tinggi Higher Education Statistical Year Book 2017 (Vol. 38, Issue 8).

[3]. de O. Santos, K. J., Menezes, A. G., de Carvalho, A. B., \& Montesco, C. A. E. (2019). Supervised Learning in the Context of Educational Data Mining to Avoid University Students Dropout. 2019 IEEE 19th International Conference on Advanced Learning Technologies (ICALT), 2161-377X, 207-208. https://doi.org/10.1109/icalt.2019.00068

[4]. Nagy, M., \& Molontay, R. (2018). Predicting Dropout in Higher Education Based on Secondary School Performance. INES 2018 - IEEE 22nd International Conference on Intelligent Engineering Systems, Proceedings, 000389000394. https://doi.org/10.1109/INES.2018.8523888

[5]. Tasnim, N., Paul, M. K., \& Sattar, A. H. M. S. (2019). Identification of Drop Out Students Using Educational Data Mining. 2nd International Conference on Electrical, Computer and Communication Engineering, ECCE 2019, 15. https://doi.org/10.1109/ECACE.2019.8679385

[6]. Mayra, A., \& Mauricio, D. (2018). Factors to predict dropout at the universities: A case of study in Ecuador. IEEE Global Engineering Education Conference, EDUCON, 2018-April, 1238-1242. https://doi.org/10.1109/EDUCON.2018.8363371

[7]. Nugroho, M. F., \& Wibowo, S. (2017). Fitur Seleksi Forward Selection Untuk Menetukan Atribut Yang Berpengaruh Pada Klasifikasi Kelulusan Mahasiswa Fakultas Ilmu Komputer UNAKI Semarang Menggunakan Algoritma Naive Bayes. Jurnal Informatika Upgris, 3(1), 63-70. https://doi.org/10.26877/jiu.v3i1.1669

[8]. Hajrahnur, S., Nasrun, M., Setianingsih, C., \& Murti, M. A. (2018). Classification of posts Twitter traffic jam the city of Jakarta using algorithm C4.5. 2018 International Conference on Signals and Systems, ICSigSys 2018 - Proceedings, 294300. https://doi.org/10.1109/ICSIGSYS.2018.8372776

[9]. Liang, S., Ma, A., Yang, S., Wang, Y., \& Ma, Q. (2018). A Review of Matched-pairs Feature Selection Methods for Gene Expression Data Analysis. Computational and Structural Biotechnology Journal, 16, 88-97. https://doi.org/10.1016/j.csbj.2018.02.005

[10]. Wang, X., Zhou, C., \& Xu, X. (2019). Application of C4.5 decision tree for scholarship evaluations. Procedia Computer Science, 151(2018), 179-184. https://doi.org/10.1016/j.procs.2019.04.027

[11], Sudarto, Zarlis, \& Pahala, S. (2016). Integrasi Density Based Feature Selection dan Adaptive Boosting (Adaboost) dalam Menangani Ketidakseimbangan Kelas. JSM (Jurnal SIFO Mikroskil), 17(2), 193-206

[12]. Muslim, M. A., Nurzahputra, A., \& Prasetiyo, B. (2018). Improving accuracy of $\mathrm{C} 4.5$ algorithm using split feature reduction model and bagging ensemble for credit card risk prediction. 2018 International Conference on Information and Communications Technology, ICOIACT 2018, 2018Janua(1996),

141-145. https://doi.org/10.1109/ICOIACT.2018.8350753

[13]. Jiang, W., Chen, Z., Xiang, Y., Shao, D., Ma, L., \& Zhang, J. (2019). SSEM: A Novel Self-Adaptive Stacking Ensemble Model for Classification. IEEE Access, 7, 120337-120349. https://doi.org/10.1109/access.2019.2933262

[14]. Gao, C., \& Grzymala-Busse, J. W. (2019). Mining incomplete numerical data sets using $\mathrm{C} 4.5$ preceded by multiple scanning. ICNC-FSKD 2018 - 14th International Conference on Natural Computation, Fuzzy Systems and Knowledge Discovery, 877884. https://doi.org/10.1109/FSKD.2018.8687148

[15]. Nugroho, H. W., Adji, T. B., \& Setiawan, N. A. (2018). Performance Improvement of C4 . 5 Algorithm using Difference Values Nodes in Decision Tree. 2018 6th 
International Conference on Cyber and IT Service Management (CITSM), Citsm, 1-6. https://doi.org/10.1109/CITSM.2018.8674250

[16]. Dabab, M., Freiling, M., Rahman, N., \& Sagalowicz, D. (2018). A decision model for data mining techniques. PICMET 2018 - Portland International Conference on Management of Engineering and Technology: Managing

Page | 272 Technological Entrepreneurship: The Engine for Economic Growth, Proceedings, 1-8. https://doi.org/10.23919/PICMET.2018.8481953 